\title{
PERSPECTIVES OF APPLICATION OF FUEL CELL ELECTRIC BUSES - SOME EXPERIENCES FROM THEIR OPERATION
}

\author{
Zlatomir Živanović ${ }^{1}$
}

UDC: $629.341 ; 629.3 .078$

DOI: $10.24874 / m v m .2017 .43 .02 .05$

\begin{abstract}
The on-going requirements for reduction of fossil fuels consumption, harmful emissions, and noise in the cities enforced the development of city buses using alternative propulsion systems as a potential answer to these requirements. Even though some improvements, as regards harmfull effects upon environment, have been accomplished by Euro VI diesel engines, no significant developments in this direction can be expected. For this reason transition to electric propulsion systems of city buses having zero emissions, such as batteries or fuel cells buses (FCBs), is imperative for many cities and city operators. The paper presents an analysis of the development of FC buses accomplished by several European projects and points at numerous problems and obstacles that have to be overcome in order to make this technology commercially sustainable. Special attention has been paid to the comparative analysis of FC buses and buses using other propulsion technologies as regards both, fuel economy and operational costs.
\end{abstract}

KEY WORDS: fuel cell buses, FC bus projects, operating cost and fuel economy, environmental benefits

\section{PERSPEKTIVA PRIMENE AUTOBUSA SA GORIVNIM ĆELIJAMA - NEKA ISKUSTVA IZ NJIHOVE EKSPLOATACIJE}

REZIME: Stalni zahtevi za smanjenjem potrošnje fosilnih goriva, štetne emisije i buke u gradovima, nametnuli su razvoj autobusa sa alternativnim pogonskim sistemima koji mogu da odgovore na postavljene zahteve. Premda su određena poboljšanja, u pogledu smanjenja štetnih efekata na životnu sredinu, dobijena sa Euro VI dizel motorima, dalji značajniji napredak, u tom pravcu, se ne može očekivati. Zato prelazak na električne pogonske sisteme autobusa sa nultom emisijom, kakvi su autobusi sa baterijama i gorivnim ćelijama je imperativ za mnoge gradove i operatere.

$\mathrm{U}$ radu se analizira dosadašnje stanje razvoja FC buses, u okviru nekoliko evropskih projekata i ukazuje na mnogobrojne probleme i prepreke koje još treba savladati da bi ova tehnologija bila komercijalno održiva. Posebna pažnja posvećena je uporednoj analizi autobusa sa gorivnim ćelijama i autobusa sa drugim tehnologijama pogona, kako u pogledu potrošnje energije, tako i ukupnih eksploatacionih troškova.

KLJUČNE REČI: Autobusi, gorivne ćelije, potrošnja energije, eksploatacioni troškovi

${ }^{1}$ Received December 2016, Accepted April 2017, Published On Line June 2017

Volume 43, Number 2, 2017 
Intentionally blank 


\title{
PERSPECTIVES OF APPLICATION OF FUEL CELL ELECTRIC BUSES - SOME EXPERIENCES FROM THEIR OPERATION
}

\author{
Zlatomir Živanović $^{1}$
}

\section{INTRODUCTION}

Fuel cell buses use compressed hydrogen as fuel and on board fuel cell(s) to generate electricity which powers the electric motor. This devices use hydrogen and oxygen to generate electricity through an electro-chemical process producing only water and heat as by-products.

Modern fuel cell electric buses in general additionally have a small battery or super capacitors. These devices improve the performance of the fuel cell and overall energy efficiency of the vehicle, for example they boost the acceleration and allow recuperation of braking energy. Apart from that, the bus structure and the other non-electric components of the bus are the same as those of conventional buses.

Fuel cell buses have the potential to provide zero emission and ultra-low carbon public transport. Because of this potential, there has been considerable research and demonstration effort dedicated to developing hydrogen bus technology. The technology is, however, not fully commercially mature and will require further public support in the coming years to stand on its own within the market.

This paper is structured in the following way:

In Section 2 are briefly presented possible FCB drivetrain configurations and descriptions of the basic components of the hybrid bus concept.

Some characteristics of fuel cell technologies are described in Section 3. They related to the operational costs of buses and infrastructure, limitations in terms of the speed of charging and range. Also, the risks arising from the use of hydrogen are pointed at.

In Section 4 are presented the most important European projects that have been realized and those whose realization is in progress, which involve a large number of partners, the bus manufacturer, European regions, and cities.

The latest generation of FCBs, which are involved in the current European CHIC (Clean Hydrogen in European Cities) project, with the main technical data is given in Section 5.

In Section 6, in the absence of European data, the comparative results of operational costs and fuel economy of FCBs and diesel buses, obtained by manufacturer Van Hool, after many years of demonstration in the United States, are shown. Data about NOx and PM emissions (per year) presented by Van Hool in its promotional materials for three different fleets of buses, are also shown.

\section{FUEL CELL BUS DRIVETRAIN CONFIGURATIONS}

Hydrogen buses have evolved substantially in the last two decades. A number of different design configurations have been used, including hydrogen in internal combustion engines, and various fuel cell technologies.

${ }^{I}$ Zlatomir Živanović, Ph.D., University of Belgrade, Institute of Nuclear Sciences "VINČA” Belgrade, Serbia 11001 Belgrade, PO Box 522, E-mail: zzivanovic@vinca.rs 
Early fuel cell bus designs involved an electric drivetrain, where a fuel cell generates electricity which is directly supplied to an electric motor.

However, this concept has been shown to have many defects related to size fuel cell systems to meet the full peak load and their overall performance and life. This concept there is no mechanism to capture the kinetic energy dissipated during braking.

In the light of these problems, all of the main fuel cell bus developers have now moved to a fully hybridized mode, with the fuel cell operating in a series hybrid configuration. In these fuel cell buses, developers are still experimenting with the energy storage device, which can be batteries, ultra capacitors, or a combination of both [1].

A third hybridized configuration is known as „,battery dominant“. In batterydominant designs, the fuel cell system is considered a „range extender"e, which recharges the battery during the drive cycle. The batteries themselves provide the main motive power for the bus.

The hybridized systems have, however, still to prove the high availability standards achieved by the non-hybridized fuel cell buses. The most recent demonstration of hybridized designs has shown availabilities generally below $80 \%$ against an average $92 \%$ achieved by the non-hybridized fuel cell buses. These next generation hybrid buses are at the beginning of their demonstration life. Most bus developers report that the availability problems come from problems in power electronics or energy storage systems as opposed to the fuel cell itself [1].

Hybridized designs, however, became the dominant choice only from 2005 . The largest fleet demonstration ever programmed started in occasion of the 2010 [1]. Today, every demonstration of fuel cell buses is based on hybrid concept, Figure 1 [2]. Key system components are: fuel cell system, energy storage system, hydrogen storage system, wheel drive, cooling system, and auxiliaries [3].

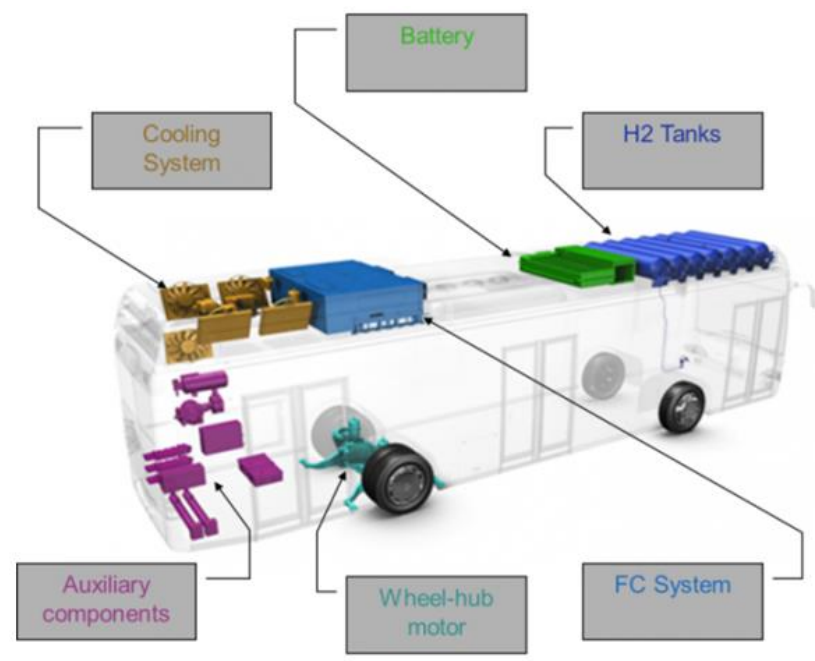

Figure 1 Key components of the fuel cell hybrid bus

Fuel cell system: A fuel cell is an energy conversion technology that allows the energy stored in hydrogen to be converted back into electrical energy for end use. In a fuel cell vehicle, an electric drive system, which consists of a traction inverter, electric motor and transaxle, converts the electricity generated by the fuel cell system to traction power to 
move a bus. The fuel cell system and additional aggregates are usually located on top of the roof of the bus.

Fuel cells are classified by their electrolyte and operational characteristics. For application in vehicles mostly used are the Polymer Electrolyte Membrane (PEM) fuel cells. They are lightweight and have a low operating temperature. PEM fuel cells operate on hydrogen and oxygen from air. Alkaline fuel cells (AFCs) are made by one of the most mature fuel cell technologies. AFCs have a combined electricity and heat efficiency of 60 percent efficient.

A newer cell technology is the Direct Methanol Fuel Cell (DMFC). The DMFC uses pure methanol mixed with steam. Liquid methanol has a higher energy density than hydrogen, and the existing infrastructure for transport and supply can be utilized.

There are some major fuel cell manufacturers supplying fuel cell power plants for heavy-duty applications: Ballard Power Systems and Hydrogenics (Canada), United Technologies Corporation (UTC) Fuel Cells, Enova Systems (USA), Shanghai Shen-Li High Tech Co. Ltd. (China), Siemens and Proton Motor Fuel Cell GmbH, (Germany), Toyota (Japan), Hyundai Motor Co. (South Korea).

Energy storage system: Energy storage systems are generally based on battery packs and/or ultra-capacitors (generally up to $100 \mathrm{~kW}$ ). Maximum power output and storage capacity vary depending on hybrid architecture. Lithium-ion battery technology is the most appropriate of energy storage technology for use in the buses. The batteries are usually located on top of the roof of the bus. FCBs are equipped with regenerative braking.

Hydrogen storage system: Gaseous hydrogen serves as the fuel. It is stored in compressed gas tanks, the number of which is decisive for the maximum range but also confines passenger capacity. The hydrogen storage system has been downsized as a result of the improved efficiency of the drive train. This has led to the reduction in the overall weight of the bus. The cylinders to storage hydrogen on board operate at an increased pressure of 350 bars.

Wheel drive: The electric motor can be either a single main motor or hub-mounted (where the motor is designed within the wheel). The bus may be equipped with a central traction system which will be located at the left hand side in the rear of the bus. The rear axle has 2 wheel hub motors and has been specifically developed to match the required speeds, load capabilities and energy efficiency. It also serves as a generator for energy regeneration during braking.

Cooling system: While running hydrogen through a fuel cell, water is of course being produced. Some of it becomes steam and leaves the system quite easily, as seen at the steam vent at the back of the bus. Yet, because PEM cells are sensitive to high heat the cell stacks must be cooled down. Therefore the by-product from producing the electricity will always partially turn into liquid water that can accumulate in the stack and slow down the process. This can happen during idle times or at full speed. Therefore all PEM cells need a mechanism that clears the stacks once in a while or else the electricity production will be slowed down. The majority of the stack manufacturers use liquid cooled systems, with radiators to dissipate heat.

Auxiliaries: The auxiliary components in the FCB may be driven electrically. This means that they operate only on demand and are not driven continuously. These solutions are typical for FCB based on hybrid concept. This will result in a higher efficiency and lower maintenance of the components. 


\section{SOME FUEL CELL TECHNOLOGY CHARACTERISTICS}

Fuel cells offer a number of potential benefits that make them appealing for transport use such as greater efficiency, quiet and smooth operation, and, if pure hydrogen is used on board the bus, zero emissions in operation and extended brake life. Infrastructure, buses, fuel, and maintenance costs associated with hydrogen fuel cells are currently prohibitively expensive. The cost of facilities has ranged from several hundred thousand dollars up to $\$ 4.4$ million for a maintenance facility, fuelling station, and bus wash [4]. Currently, fuel cells for buses are not a commercial product. The existing fuel cell buses are prototypes, manufactured in fairly small numbers. FCB technology continues to show progress toward meeting technical targets for increasing reliability and durability while also reducing costs. Fuel cell buses can cost $\$ 2.1$ to $\$ 2.4$ million (or more) since they are handbuilt prototypes utilizing a pre-commercial technology.

The purchase cost of FCBs has been cut by 50\% since 2011 [5], but their purchase price after 2015 to 2025 will be decreased by account $75 \%$ [6].

The hydrogen fuel itself is also currently very expensive. Costs range depending on the method of hydrogen production. One of the major constraints for use of the fuel cell buses is the refuelling time for hydrogen buses. Filling over $30 \mathrm{~kg}$ of hydrogen in less than 5 minutes is not currently feasible without pre-cooling the hydrogen (as the temperature increase at these high fill rates would damage the hydrogen tanks) [1].

Hydrogen fuel cell buses have shown very good performance during trials and have high route flexibility, comparable to diesel buses [7].

Cost premiums and lack of infrastructure are proving to be a barrier to most at this stage and there are some reports of problems with the current range of the vehicles, practical difficulties of storing fuels, planning issues with storage facilities and the availability of fuel. Legislation on the use of hydrogen as a fuel is immature, with much of it based on the industrial use of hydrogen.

Due to the risk of explosion, hydrogen buses are not allowed to be used indoors, in garages or underground and even long tunnels in some cases. A possible solution would be to use bio methanol and convert it to hydrogen only when it is used [7].

Hydrogen as a road fuel yields significant potential for carbon neutrality on a wellto-wheel basis along the entire hydrogen value chain, including production and means of delivery. Hydrogen can be produced with electricity from $100 \%$ renewable energy sources. Hence, operating FC buses can be achieved with zero $\mathrm{CO}_{2}$ emissions along the entire hydrogen value chain. By using hydrogen produced from renewable energy sources only, one standard FC bus would save approximately 800 tons of $\mathrm{CO}_{2}$ in its lifetime of 12 years compared to a conventional diesel bus [8].

\section{FUEL CELL BUS PROJECTS}

The introduction of new types of buses in urban public transport is sometimes a challenging process that includes testing, demonstration and limited production with a tendency to increase the number of vehicles. Fuel cell-powered buses continue to be demonstrated in public transport service at various locations around the world. Many demonstration projects have been launched in the last 10 years in various stages of implementation. Many have been completed, and some of them are still active. An overview of mainly fuel cell city bus development projects is given below: 
CUTE (Clean Urban Transport for Europe) (2001-2006): The Clean urban Transport for Europe $[9,10]$ was a European project which saw the deployment and testing of 27 Citaro fuel cell buses - three buses in each of nine cities in Europe. The aim of the project was to demonstrate the feasibility of an innovative, highly energy-efficient, clean urban public transport system. Different hydrogen production and refuelling infrastructures were established in each of the cities. The project saw practical applications of renewable energy sources to the transport system. The project greatly improved public acceptance of the hydrogen fuel cell transport system, and contributed to the development of a more secure energy supply for the EU.

(ECTOS (Ecological City TranspOrt System) [11] was an initiative to test three Citaro fuel cell buses in Reykjavik, Iceland. The project was financially supported by the European Commission.) The overall objective of ECTOS was to implement a demonstration of state-of-the-art hydrogen technology by running part of the public transport system with fuel cell buses within Reykjavík. The energy chain was close to $\mathrm{CO}_{2}$ free, because domestic geothermal and hydro-powered energy sources were used to produce hydrogen by electrolysis. The main research objectives concerned the socio-economic factors involved in changing the energy base of a modern urban society.

HyFLEET:CUTE (2006-2009) [10] has involved the operation of 47 hydrogen powered buses in regular public transport service in 10 cities on three continents. Its aim was to diversify and reduce energy consumption in the transport system by developing new, fuel efficient hydrogen powered bus technology, clean, efficient and safe production and distribution of hydrogen as a transport fuel. HyFLEET:CUTE was co-funded by the European Commission and 31 Industry partners through the Commission's 6th Framework Programme. The HyFLEET:CUTE project demonstrated in particular major developments in further development of Hydrogen Powered Bus Technology, and further development of Hydrogen Infrastructure.

"NaBuZ demo" (Sustainable Bus System of the Future - Demonstration) is German-funded project [12] in which the Hamburger Hochbahn AG produced four Mercedes-Benz CitaroFuelCELLHybrid buses. Since 2011, the first CitaroFuelCELL Hybrid bus is involved into service.

In contrast to the fuel cell buses which have been tested in Hamburg since 2003, the new CitaroFuelCELL Hybrid, part of the "NaBuZ project", boasts significant new features. For example, hybridization with energy recuperation and storage in lithium-ion batteries, high-performance electric motors with $120 \mathrm{~kW}$ continuous outputs in the wheel hubs, as well as electrified auxiliary aggregates and advanced fuel cells. This should make an extended service life of at least six years or 12,000 operating hours possible.

A new feature is the lithium-ion batteries which store energy recovered from braking. The power from these batteries alone is enough to drive the CitaroFuelCELL Hybrid over several kilometres. The concept for the new FuelCELL buses is actually very similar to that of the Mercedes-Benz BlueTec Hybrid buses which are also operated in Hamburg. The main difference between the two lies with the diesel generator of the BlueTec Hybrid buses, which supplies the latter with electrical energy. With the FuelCELL buses, the fuel cell supplies the drive motors with energy in a $100 \%$ emission-free process.

CHIC (Clean Hydrogen In European Cities) [13,14] is a major European project to deploy a fleet of fuel cell electric buses and associated refuelling infrastructure. CHIC builds on the expertise acquired in the framework of previous fuel cell bus projects: The HyFLEET:CUTE and CUTE project.

The European Fuel Cells and Hydrogen Joint Undertaking (FCH JU) public private partnership has co-funded 26 buses and their infrastructure in: Aargau (Switzerland), Bozen 
(Italy), London (UK), Milan (Italy) and Oslo (Norway), Figure 1. In Germany, Cologne and Hamburg operate an additional fleet of 10 buses through separately funded programs, and an additional 20 buses were deployed in Whistler (Canada).

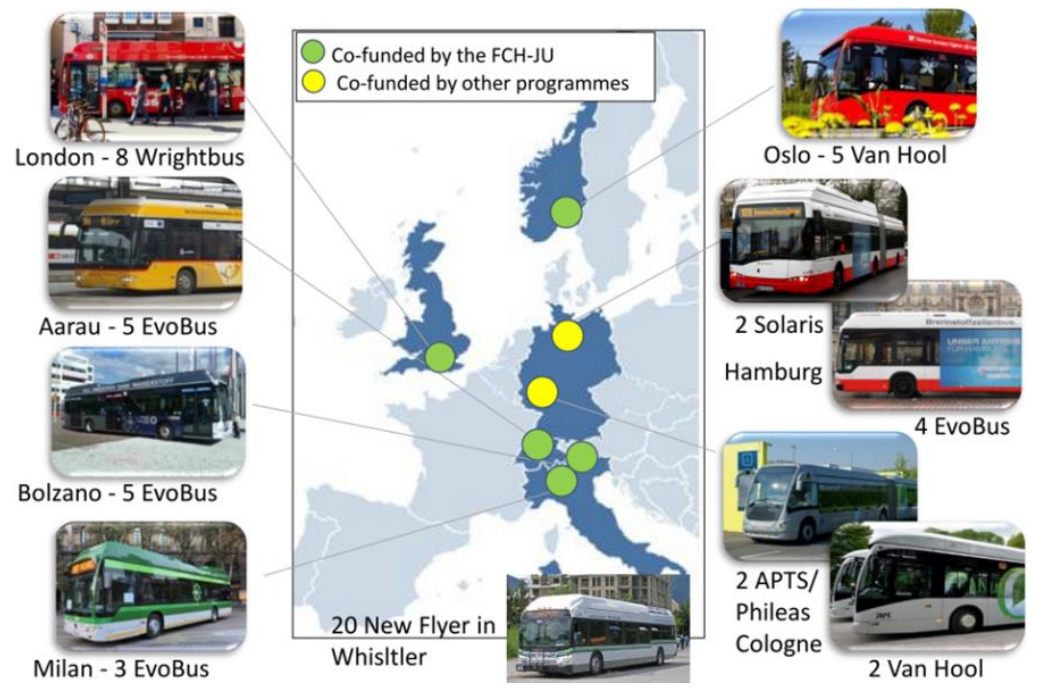

Figure 2 Participating cities and bus manufacturers in the GHIC project

In the time period from 2010 to 2016 , the buses are tested for their reliability and sustainability and the participating cities gather both data on bus and infrastructure performance. At the same time dissemination activities should be put in place in order to raise public awareness regarding hydrogen technology and its applications.

Hamburg is a front runner in trialling fuel cell buses: Between 2003 and 2009, up to 9 EvoBus fuel cell buses have been operated, carrying 1.9 million passengers over $700,000 \mathrm{~km}$. Four $12 \mathrm{~m}$ EvoBus fuel cell buses are in operation since 2011. Two $18 \mathrm{~m}$ Solaris battery electric buses with fuel cells as range extender started their operation in January 2015. The buses have a $400 \mathrm{~km}$ range and operate between 8 and 16 hours daily [14].

Most of the fuel cell buses today are running on European and North-American streets, while additional buses are being demonstrated in other parts of the world, for example in Japan and Brazil. Over 90 fuel cell electric buses are in operation today in Europe or about to start operation, Figure 2 [16]. 


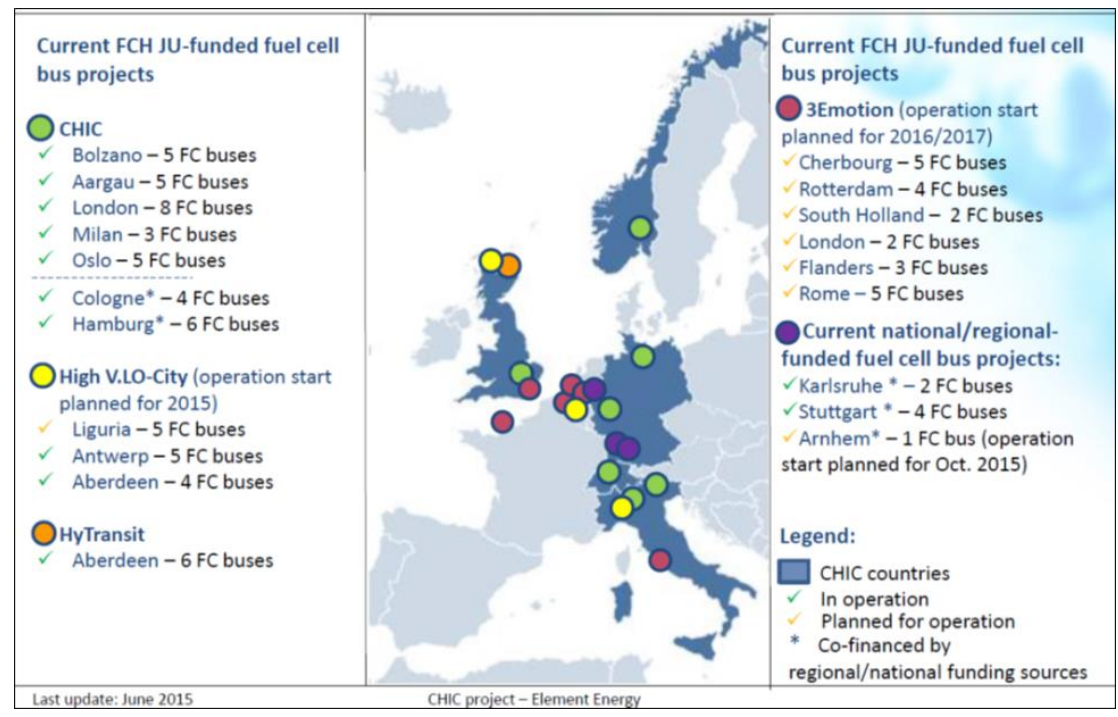

Figure 3 Fuel cell buses in operation or about to start operation

\section{NEW GENERATION OF FUEL CELL BUSES}

In this section are given basic information about the new generation of $\mathrm{FC}$ buses involved in the European CHIC project.

Mercedes-Benz fuel cell hybrid buses: Production of the second generation of Mercedes fuel-cell hybrid buses started in November 2010 under the CHIC project. Compared with the fuel cell buses which were tested in Hamburg in 2003, the new Citaro FuelCELL Hybrid, Figure 4, provides several significant new features [17]: hybridization with energy recovery and storage in lithium-ion batteries, powerful electric motors with 120 $\mathrm{kW}$ of continuous output in the wheel hubs, electrified power take-off units and further enhanced fuel cells. These should achieve an extended service life of at least six years or 12.000 operating hours.

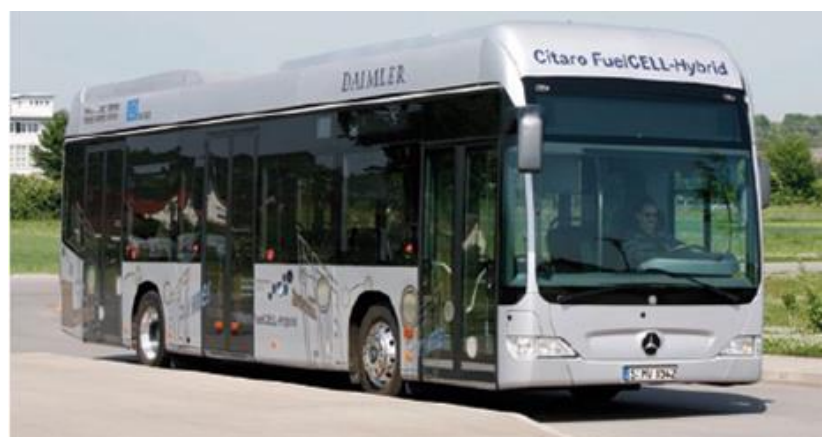

Figure 4 The new Citaro FuelCELL hybrid bus

New additions are the lithium-ion batteries which for example store recovered energy. With the power stored there the new Citaro FuelCELL Hybrid can drive several 
kilometres on battery operation alone. In general, the design of the new FuelCELL buses is largely the same as that of the Mercedes-Benz BlueTec Hybrid buses that run in regular service; these buses also get electrical energy from a diesel generator. Thanks to improved fuel cell components and hybridization with lithium-ion batteries the new Citaro FuelCELL Hybrid saves on almost $50 \%$ in hydrogen usage compared with the preceding generation. Overall fuel cell system efficiency has also been improved. The fuel cell bus has a range of around 250 kilometres.

Van Hool fuel cell hybrid buses: VAN HOOL (Belgium) is the largest independent manufacturer of integral buses and coaches in Western Europe. More than $80 \%$ of the company's production is exported: two thirds stay in Europe, the remainder goes to America, Africa and Asia. In a joint effort with UTC Power (United Technologies Corporation), a supplier of fuel cell systems, Van Hool developed fuel cell buses for the European and US markets. Siemens supplied the twin AC induction electric motor, $85 \mathrm{~kW}$ each, converters, and adapted traction software.

Within the project ZEBA demonstration includes 12 new generation fuel cell hybrid buses and two new hydrogen fuelling stations [18]. The buses are $12 \mathrm{~m}$, low floor, with a hybrid electric propulsion system that includes a UTC Power fuel cell power system $(120 \mathrm{~kW})$ and an advanced lithium-ion battery (rated energy: $17.4 \mathrm{kWh}$ and rated power: 76 to $125 \mathrm{~kW}$ ). Eight Dynetek, type 3 cylinders, 350 bars, are mounted on the roof. The new buses, Figure 5, feature significant improvements over two previous generations of fuel cell buses that were demonstrated in California, Connecticut, and Belgium. Improvements include a redesigned Van Hool chassis that is lighter in weight, shorter in height, and has a lower centre of gravity for improved weight distribution. The bus has a top speed of $55 \mathrm{mph}$ $(88 \mathrm{~km} / \mathrm{h})$. The bus purchase cost is about $\$ 2.5$ million [18].

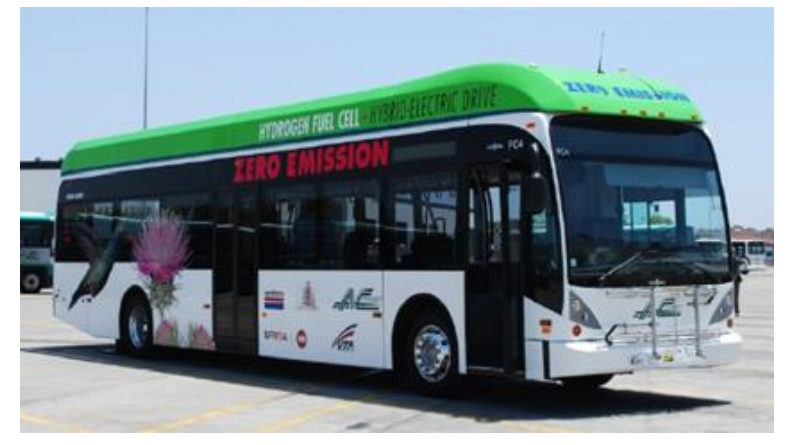

Figure 5 The new Van Hool fuel cell bus

The two hydrogen buses for London are hybrid (fuel cell and battery powered) Van Hool A330 model 12-metre bus with two axles. They are equipped with the very latest FCvelocity-HD7 Fuel Cell module from Ballard Power Systems in Vancouver, Canada [19]. The hybrid drive system will enable the buses, with a tank content of $30 \mathrm{~kg}$ of hydrogen on board, to travel the planned daily distance of $300 \mathrm{~km}$ for TfL (Transport for London).

The drive system is based on fuel cells, lithium batteries and electric motors. The bus runs entirely on electricity. This hybrid drives system and the reuse of braking energy limits hydrogen consumption to around $8 \mathrm{~kg}$ per $100 \mathrm{~km}$.

Van Hool has already supplied 49 hydrogen buses to the US and to European member states as part of other European projects, including five buses to De Lijn Antwerp (Belgium). 
Wrightbus fuel cell hybrid buses: The buses are VDL SB200 single decker with Pulsar bodywork, supplied by ISE Corporation in collaboration with Wrightbus and Ballard, Figure 6. The hybrid drivetrain (ISE's Thunder Volt drive system) is based on super capacitors and is powered by Ballard's FC velocity-HD6 $75 \mathrm{~kW}$ fuel cell system. The buses carry approx. $42 \mathrm{~kg}$ of useable gaseous hydrogen at 350 bar [20]. Transport for London's new FC bus project is being supported by the Department of Energy and Climate Change and the European Commission's Joint Technology Initiative as a part of the CHIC project.

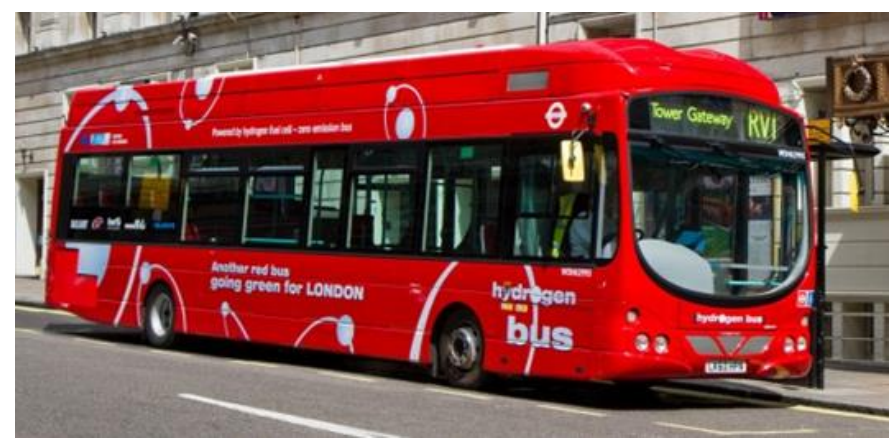

Figure 6 The Wrightbus wit fuel cells

The Phileas fuel cell hybrid buses: The Phileas hybrid FC buses, Figure 7, are based on an innovative 18 meters low-floor lightweight triple-axle platform, which can carry 35 seated and up to 120 standing passengers [20]. The composite body was developed by Advanced Public Transport Systems BV (APTS); the hybrid drivetrain has been developed by Vossloh Kiepe GmBH using super capacitors, HOPPECKE's battery and Ballard's FC velocity-HD6 $150 \mathrm{~kW}$ fuel cell system. The buses carry $42 \mathrm{~kg}$ of useable gaseous hydrogen at 350 bars.

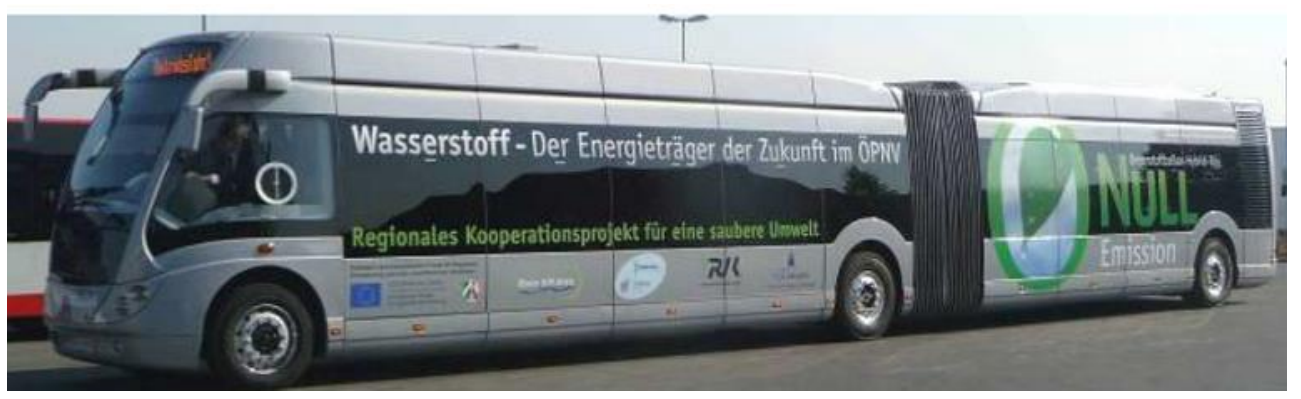

Figure 7 The Phileas hybrid FC bus

First Solaris Urbino 18.75 electric with hydrogen fuel cells: To provide its latest electric buses with energy, Solaris is applying hydrogen fuel cells for the first time. So far no one in the Polish automotive industry has used this ultra-modern technology. The first of two Urbino 18.75 electric had its world premiere in Hamburg, on 18th December 2014 [21]. These innovative Solaris buses, Figure 8, are equipped with $120 \mathrm{kWh}$ batteries as the main energy provider to the drive system. They will be charged by Ballard $101 \mathrm{~kW}$ fuel cells during operation. A novelty is that the fuel cells are used only when $100 \%$ of output is required, which significantly increases their 
durability. The bus will be fuelled with hydrogen at night in the depot. Battery charging cycles will be pre-programmed so it will be ready to cover $300 \mathrm{~km}$ per day.

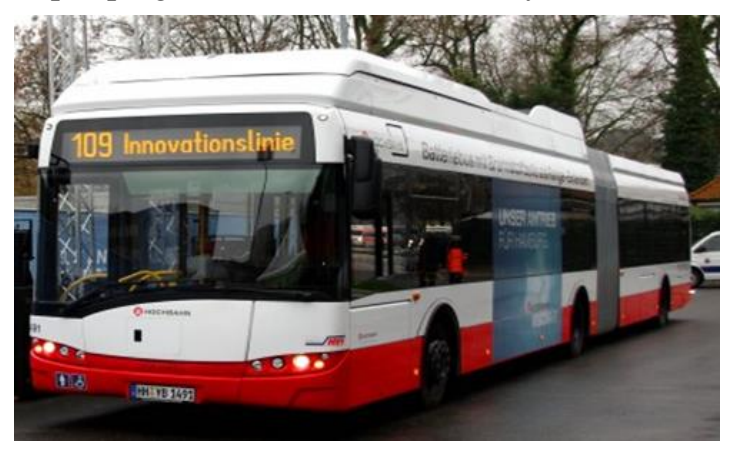

Figure 8 The Solaris electric bus with hydrogen fuel cells

The Solaris Urbino 18.75 electric with fuel cell range extender has great potential to make a difference in urban public transport. The vehicle is eminently suited to play that role. Its innovative technology has already been appreciated in Germany. The new electric bus for Hamburg is the most technologically advanced Solaris product so far. With the Urbino 18.75 electric with fuel cells, Solaris adds a new innovative solution to its range of battery charging options. Plug-in, inductive and pantograph charging now are accompanied by fuel cells as range extenders [21].

\section{SOME RESULTS FROM FUEL CELL BUS OPERATIONS}

Many transport operators continue to aid the FCB industry in developing and optimizing advanced transportation technologies. These in-service demonstration programs are necessary to validate the performance of the current generation of fuel cell systems and to determine issues that require resolution.

\subsection{Operating cost and fuel economy}

The results presented in this section are focused on data optained from operating of 12 Van Hool FCBs, Table 1, in United States from November 2013 through December 2014 [22], as a part of the Zero Emission Bay Area (ZEBA) demonstration.

National Renewable Energy Laboratory (NREL) has been evaluating that results includes baseline data from four Van Hool diesel buses that are the same model as the FCBs. During that data period, the FCBs operated 417,757 miles $(672,171 \mathrm{~km})$ over 49,421 hours of fuel cell operation. This indicates an overall operational speed of $8.5 \mathrm{mph}$ (13.7 $\mathrm{km} / \mathrm{h}$ ) [22].

Table 1 provides bus system descriptions for the fuel cell and diesel bus that were analysed. 
Table 1 System description of the analyzed buses

\begin{tabular}{|c|c|c|}
\hline Bus system & Fuel cell bus & Diesel bus \\
\hline $\begin{array}{l}\text { Image } \\
\text { of bus }\end{array}$ & & \\
\hline Number of buses & 12 & 4 \\
\hline Bus manufacturer/model & Van Hool A300L FC low floor & Van Hool A300L FC low floor \\
\hline Model year & 2010 & 2009 \\
\hline Passenger capacity & $\begin{array}{c}33 \text { seated or } 29 \text { seated plus } 2 \\
\text { wheelchairs }\end{array}$ & $\begin{array}{c}31 \text { seated or } 28 \text { seated plus } 2 \\
\text { wheelchairs }\end{array}$ \\
\hline Engine manufacturer/model & US Hybrid fuel cell power system & Cummins ISL, $8.9 \mathrm{~L}$ \\
\hline Rated power & Fuel cell power system: 120 kW & 280 hp @ 2,200 rpm \\
\hline Transmission/retarder & $\begin{array}{l}\text { Seico brake resistors } \\
\text { regenerative braking }\end{array}$ & $\begin{array}{c}\text { Voith } \\
\text { integrated retarder }\end{array}$ \\
\hline Bus purchase cost & $\$ 2.5$ million & $\$ 323,000$ \\
\hline
\end{tabular}

Table 2 presents the comparative test results for the fuel cell and diesel buses during the evaluating period. The FCBs had an overall average fuel economy of 7.23 miles per diesel gallon equivalent (DGE) or $3.07 \mathrm{~km} / \mathrm{litre}$, but Van Hool diesel buses had an overall average fuel economy 3.95 mile per DGE $(1.68 \mathrm{~km} / \mathrm{litre})$. These results indicate that the FCBs have an average fuel economy that is $83 \%$ higher than that of the Van Hool diesel buses. Data for the fuel economy in miles per DGE are converted into km/litre (1 mile per DGE $=0.425 \mathrm{~km} / \mathrm{litre}$ ).

Table 2 Operating costs and fuel economy of different buses

\begin{tabular}{|c|c|c|}
\hline & Fuel Cell & Diesel \\
\hline Fuel Cost $(\$ / \mathrm{km})$ & 0.88 & 0.47 \\
\hline Total Maintenance Cost $(\$ / \mathrm{km})$ & 0.38 & 0.46 \\
\hline Total Operating Cost $(\$ / \mathbf{k m})$ & $\mathbf{1 . 2 6}$ & $\mathbf{0 . 9 4}$ \\
\hline Fuel economy $(\mathbf{k m} /$ litre $)$ & $\mathbf{3 . 0 7}$ & $\mathbf{1 . 6 8}$ \\
\hline
\end{tabular}

The cost of hydrogen production as dispensed during this period was $\$ 9.10$ per kilogram, not including the capital cost of the station. The hydrogen fuel cost per $\mathrm{km}$ calculates to $\$ 0.88$. Diesel fuel cost during the reporting period was $\$ 0.76$ per litre, which calculates to $\$ 0.47$ per $\mathrm{km}$ for the Van Hool diesel buses.

\subsection{Environmental benefits}

Emitting water only, FC buses are zero exhaust emission vehicles and can greatly contribute to reducing emissions in cities. Furthermore, they run at significantly lower noise levels. Standing and in motion, FC buses reduce perceived noise levels by almost two thirds compared to conventional diesel buses, Figure 9 [8]. 


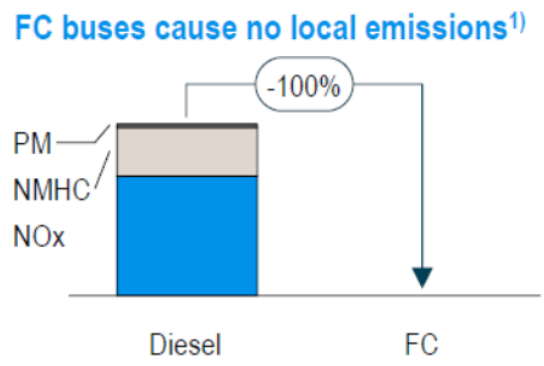

1) Local emissions for 1 litre of diesel fuel according to EURO VI norm

2) Non-linear $\mathrm{db}$ scale; $-10 \mathrm{db}=50 \%$ noise reduction; noise levels vary depending on terrain and driving style
FC buses reduce noise levels

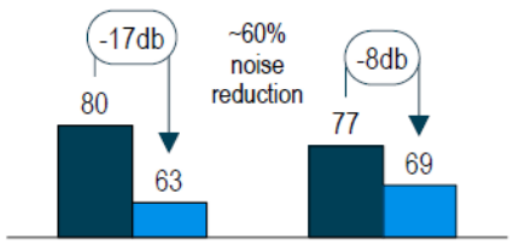

Not moving

In motion

Figure 9 Comparison of local emission and noise levels of diesel and FC buses

Data about $\mathrm{NO}_{\mathrm{x}}$ and $\mathrm{PM}$ emissions (per year) presented by Van Hool in its promotional materials for three different fleets of buses, are shown in Table 3 [23]. The data are calculated for $50.000 \mathrm{~km}$ per year, average speed $20 \mathrm{~km} / \mathrm{h}$, and power consumption 50 $\mathrm{kW} / \mathrm{h}$.

Table 3 Comparative characteristics of NOx and PM emissions for different buses

\begin{tabular}{|c|c|c|}
\hline & NO $_{\mathbf{x}}($ per year) & PM (per year) \\
\hline $\mathbf{1 0 0}$ Diesel Euro III buses & 62.5 tons & 1.25 tons \\
\hline $\mathbf{1 0 0}$ CNG buses & 25 tons & 0.25 tons \\
\hline $\mathbf{1 0 0}$ Hybrid fuel cell buses & zero & zero \\
\hline
\end{tabular}

Equivalent emissions reduction potential of 100 hybrid fuel cell buses gives a $\mathrm{CO}_{2}$ reduction equal to the uptake of 3.100 acres of forest and a $\mathrm{NO}_{\mathrm{x}}$ reduction equal to $10 \mathrm{~km}$ of 4 lanes of cars [23]. The presented results show all the environmental advantages of the buses with fuel cell technologies.

Some comparisons with different bus technologies (diesel, diesel-hybrid and fuel cell), in terms of $\mathrm{CO}_{2}$ emissions per $\mathrm{km}$ travelled, have shown potentially significant benefits of FCB. Data below summarises the range of $\mathrm{CO}_{2}$ emissions per kilometre for hybrid fuel cell buses compared with diesel and diesel hybrid buses [6].

- Fuel cell buses: 0 to $1.8 \mathrm{~kg} / \mathrm{km}$. Zero emissions are related to renewable hydrogen and electricity.

- Diesel-hybrid buses: 0.69 to $1.2 \mathrm{~kg} / \mathrm{km}$

- Diesel buses: 1.05 to $1.5 \mathrm{~kg} / \mathrm{km}$.

There is a very wide range for fuel cell buses, reflecting the wide range in $\mathrm{CO}_{2}$ emissions for different hydrogen production pathways. At the ultra-low $\mathrm{CO}_{2}$ end (production from renewable, nuclear or fossils fuels with Carbon Capture and Storage (CCS) technology) the $\mathrm{CO}_{2}$ emissions are over $90 \%$ lower than a conventional diesel bus.

At today's state of the art for hydrogen production from methane (approx. 10 $\mathrm{kgCO}_{2} / \mathrm{kg}$ of $\mathrm{H}_{2}$ ), there is still a $\mathrm{CO}_{2}$ advantage over both diesel and diesel hybrid buses at the highest fuel economy for fuel cell buses.

This suggests that any medium term strategy for hydrogen bus rollout should target a $\mathrm{CO}_{2}$ content below $10 \mathrm{kgCO}_{2} / \mathrm{kg}$ of hydrogen and best in class fuel economy, to ensure that the deployment leads to real $\mathrm{CO}_{2}$ savings. 


\section{CONCLUSIONS}

Analysis of FC bus drivetrain configuration showed that the initial solution of the buses was based on configurations where a fuel cell generates electricity which is directly supplied to an electric motor.

Hybridized designs with energy storage device where the fuel cell, operating in a series hybrid configuration, became the dominant choice starting from 2005 and especially after 2010. Today, every demonstration of fuel cell buses is based on the hybrid concept.

A large number of current and completed FC bus projects demonstrate a growing interest of stakeholders and bus manufacturer to invest in the development of these technological solutions.

Lessons learned from past demonstration projects show that fuel cell buses have the potential to be operated with the same operational flexibility as a conventional diesel bus, whilst offering zero tailpipe emissions, contribution to decarbonisation of transport, reduced noise and vibration levels.

FCBs that run on hydrogen derived from $100 \%$ renewable source, offer a significant reduction in GHG emissions on a well-to-wheels basis.

Some reports indicate that the performances of fuel cell buses in-service are above expectation. One of the many barriers to their wider use is the uncertainty of hydrogen supplies and high production costs of hydrogen. Other barriers are related to the cost of fuel cells, energy storage device, and the security aspects of usage of these vehicles.

Since FC buses have a very favourable energy and environmental potential, which contributes significantly to sustainable public transport, one should expect their intensive development and commercialization in the immediate future.

\section{ACKNOWLEDGEMENT}

This work was financially supported by the Ministry of Education, Science and Technological Developments Republic of Serbia (Projects No. TR 35041, TR 35042).

\section{REFERENCES}

[1] Zaetta R, Madden B. Hydrogen Fuel Cell Bus Technology State of the Art Review, Project EC FCH-JU-2008-1 Grant Agreement Number 245133, Report Version 3.1, 2011, http://nexthylights.eu/Publications/Clean-3 D31_WP3_EE_State_of_the_Art_23rd-FEB-2011.pdf, accessed 19 May 2016.

[2] The CHIC Project, Fuel cells and fuel cell buses, http://chicproject.eu/technology/fuel-cell-buses\#prev, accessed 20 May 2016.

[3] Zlatomir Živanović, Zoran Nikolić: The Application of Electric Drive Technologies in City Buses (Book chapter). In: Stevic Z. (ed) NEW GENERATION OF ELECTRIC VEHICLES, InTech, Rijeka, 2012, p. 165-203, ISBN 978-953-51-0893-1, DOI: 10.5772/51770.

[4] Allison B, Spencer C, Hannah P, Claire P, Kayla R. The Feasibility of Alternative Fuels and Technologies: An Assessment of Addison County Transit Resources' Current and Future Options, Middlebury College, 2008. http://www.middlebury.edu/media/view/255373/original/BUSFINALREPORT.pdf , accessed 20 May 2012.

[5] CHIC, Clean Hydrogen in European Cities, http://www.hydrogenlondon.org/wpcontent/uploads/2015/11/CHIC leaflet.pdf, accessed 20 May 2016. 
[6] Paul Jenné: Fuel Cell Electric Bus Projects - Status and Outlook from an Industry Perspective, Lyon, April 22-23, 2015, http://www.fch.europa.eu/sites/default/files/Van\%20Hool\%20\%20WorkshopLyon_22042015\%20(ID\%202436334)\%20(ID\%202497332).pdf, accessed 20 May 2016.

[7] Clean Buses - Experiences with Fuel and Technology Options, The Clean Fleets project, February 2014 http://www.clean-fleets.eu/fileadmin/files/Clean_Buses_Experiences_with_Fuel_and_Technology_Options_2.1.pdf, accessed 20 May 2016.

[8] Heiko Ammermann, Yvonne Ruf, Simon Lange, Dragos Fundulea, André Martin: Fuel Cell Electric Buses - Potential for Sustainable Public Transport in Europe, A Study for the Fuel Cells and Hydrogen Joint Undertaking, Roland Berger GmbH, September 2015 , http://www.fch.europa.eu/sites/default/files/150909_FINAL_Bus_Study_Report_O UT 0.PDF, Accessed 20 May 2016.

[9] CUTE, Clean Urban Transport for Europe, http://www.global-hydrogen-busplatform.com/www.global-hydrogen-bus-platform.com/About/History/CUTE.html, accessed 20 May 2016.

[10] The CHIC Project, History, http://chic-project.eu/about-us/history, accessed 20 May 2016.

[11]ECTOS, Ecological City TranspOrt System, http://www.global-hydrogen-busplatform.com/www.global-hydrogen-bus platform.com/About/History/ECTOS.html, accessed 20 May 2012.

[12] NaBuZ project in Hamburg, The online portal "Fuel-Cell e-Mobility", http://www.fuel-cell-e-mobility.com/specials-events-en/demonstrationprojects/nabuz-demo-project-en/, accessed 20 May 2016.

[13] The CHIC Project, Institute for Innovative Technologies Ltd, Bolzano http://www.h2-suedtirol.com/en/projects/chic/, accessed 20 May 2016.

[14] Clean Hydrogen in European Cities project, Presentation of the emerging conclusions, short version, February 2016, http://chic-project.eu/wpcontent/uploads/2016/03/CHIC-Emerging-Conclusions short_Feb2016.pdf, accessed 20 May 2016.

[15] "The CHIC Project, Hamburg, http://chic-project.eu/demonstration-sites/hamburg, accessed 20 May 2016.

[16] The CHIC Project, Fuel cell buses outside CHIC http://chic-project.eu/fuel-cellbuses-in-europe, accessed 20 May 2016.

[17] Hamburg putting its first Citaro FuelCELL Hybrid buses into service, Green Car Congress, 2011, http://www.greencarcongress.com/2011/08/hamburg-putting-itsfirst-citaro-fuelcell-hybrid-buses-into-service-hamburger-hochbahn-ag-hasacquired-four-mercedes-benz.html, accessed 4 March 2012.

[18] Kevin C, Leslie E. Zero Emission Bay Area (ZEBA), Fuel Cell Bus Demonstration: First Results Report, Technical Report, NREL/TP-5600-52015, August 2011, http://www.nrel.gov/hydrogen/pdfs/52015.pdf, accessed 10 May 2012.

[19] Dirk Snauwaert: Van Hool delivers two fuel cell buses for London, Van Hool, 2015, https://www.vanhool.be/ENG/actua/2fuelcellbuseslo.html, accessed 20 May 2016.

[20] The Hydrogen Bus Alliance Annual Review, HBA Activities on Hydrogen Buses, 2011, http://www.h2euro.org/wp-content/uploads/2011/09/The-Hydrogen-BusAlliance-Annual-Review-2011-final-2.pdf, accessed 20 May 2016. 
[21] First Solaris Urbino 18.75 electric with hydrogen fuel cell range extenders presented in Hamburg, SOLARIS Bus \& Coach S.A., December 2014, http://chicproject.eu/newsevents/news/hamburg-the-first-bus-innovation-line-in-europeincludes-fuel-cells-buses, accessed 20 May 2016.

[22] Leslie Eudy and Matthew Post:. Zero Emission Bay Area (ZEBA), Fuel Cell Bus Demonstration Results: Fourth Report, Technical Report, NREL/TP-5400-63719, July 2015, http://www.nrel.gov/docs/fy15osti/63719.pdf, accessed 10 June 2016.

[23] Hybrid fuel cell buses, Van Hool NV, Belgium, https://www.vanhool.be/Home\%20FR/transport\%20public/hybride\%20pile\%20a\% 20combustible/Resources/folderFuelCell.pdf, accessed 20 May 2016. 